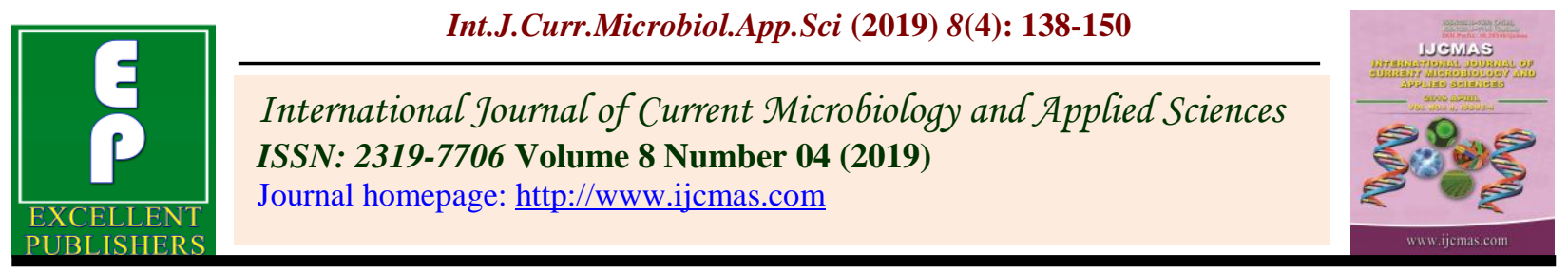

Original Research Article https://doi.org/10.20546/ijcmas.2019.804.015

\title{
Impact of INM on Growth and Yield of Maize (Zea mays) Crop in Central Plain Zone of Uttar Pradesh, India
}

\author{
Priyavart Mishra, U.S. Tiwari, Hanuman Prasad Pandey*, \\ R.K. Pathak and A.K. Sachan \\ Department of Soil Science and Agricultural Chemistry \\ C.S. Azad University of Agriculture and Technology, Kanpur, Uttar Pradesh - 208002, India \\ *Corresponding author
}

A B S T R A C T

\begin{tabular}{|l|}
\hline Ke y w o r d s \\
Zea mays, Growth, \\
Yield, Azad Uttam, \\
FYM, Grain, Stalk \\
\hline Article Info \\
\hline $\begin{array}{l}\text { Accepted: } \\
\text { 04 March } 2019 \\
\text { Available Online: } \\
\text { 10 April } 2019\end{array}$ \\
\hline
\end{tabular}

A field experiment was conducted at field no. 6 Student's Instructural Farm at Chandra Shekhar Azad University of Agriculture and Technology, Kanpur during the Kharif season 2017 to find out integrated nutrient management effect on maize with ten treatments i.e. $\mathrm{T}_{1}$ $(125 \% \mathrm{RDN}), \mathrm{T}_{2}(100 \% \mathrm{RDN}), \mathrm{T}_{3}(100 \% \mathrm{RDN}+25 \% \mathrm{~N} \mathrm{FYM}), \mathrm{T}_{4}(100 \% \mathrm{RDN}+25 \% \mathrm{~N}$ $\left.\mathrm{FYM}+\mathrm{S}_{30}\right), \mathrm{T}_{5}\left(100 \% \mathrm{RDN}+25 \% \mathrm{NFYM}+\mathrm{S}_{30}+\mathrm{Zn}_{5}\right), \mathrm{T}_{6}(75 \% \mathrm{RDN}), \mathrm{T}_{7}(75 \% \mathrm{RDN}+$ $25 \% \mathrm{~N} \mathrm{FYM}), \mathrm{T}_{8}\left(75 \% \mathrm{RDN}+25 \% \mathrm{~N} \mathrm{FYM}+\mathrm{S}_{30}\right), \mathrm{T}_{9}\left(75 \% \mathrm{RDN}+\mathrm{FYM}+\mathrm{S}_{30}+\mathrm{Zn}_{5}\right)$, $\mathrm{T}_{10}$ (Control) in RBD with 3 replications. Maize variety Azad Uttam was taken for study. The results revealed that the grain and stalk yield of maize respond significantly with the different treatment combination. The result showed highest grain yield $\left(35.25 \mathrm{q} \mathrm{ha}^{-1)}\right.$ and stalk yield (97.99 $\mathrm{q} \mathrm{ha}^{-1}$ ) with the application of $100 \% \mathrm{RDN}+25 \% \mathrm{~N} \mathrm{FYM}+\mathrm{S}_{30}+\mathrm{Zn}_{5} \mathrm{ha}^{-}$ 1 , which was $88 \%$ and $63.31 \%$ higher to lowest grain yield $\left(18.75 \mathrm{q} \mathrm{ha}^{-1}\right)$ and stalk yield $\left(60 \mathrm{q} \mathrm{ha}^{-1}\right)$ at control. The maximum growth and yield in case of all treatments was found in $\mathrm{T}_{5}\left(100 \% \mathrm{RDN}+25 \% \mathrm{~N} \mathrm{FYM}+\mathrm{S}_{30}+\mathrm{Zn}_{5}\right)$ and lowest in $\mathrm{T}_{10}(\mathrm{Control})$.

\section{Introduction}

Maize (Zea mays L.) is one of the most important cereal crop, next to rice and wheat and is used as a food for human and feed for animals. This crop has been developed into a multi dollar business in countries viz. Thiland, Tiwan, Singapore, Malaysia, USA, Canada and Germany, because of its potential as a value added product for export and a good food substitute. Maize is gaining immense importance on account of its potential uses in manufacturing starch, plastics, rayon, adhesive, dye, resins, boot polish etc. and due to this large uses it is rightly called a Miracle crop and also known as 'Queen of cereals' due to its high potential yield. In India, maize is grown in an area of 9.76 million hectares with production of 26.14 million tonnes and productivity of $2629.28 \mathrm{~kg} \mathrm{ha}^{-1}$ (Government of India, 2017). Maize yield is generally higher in high solar intensities, lower night temperature and lower pest infestation. Optimum plant density leads to better utilization of solar radiation resulting into corn dry matter accumulation and biomass production. Uttar Pradesh is the major producing state contributes 60 percent area 
and 70 percent of maize production in India. Abbasi et al., (2010) reported that application of the highest rate of $\mathrm{N}\left(150 \mathrm{~kg} \mathrm{ha}^{-1}\right)$ recorded the highest grain yields (3763 kg ha ${ }^{-1}$ ) of maize. The proportional increase in maize yield for Nitrogen $\left(90 \mathrm{~kg} \mathrm{~N} \mathrm{ha}^{-1}\right)+$ poultry manure $\left(30 \mathrm{~kg} \mathrm{~N} \mathrm{ha}^{-1}\right)$ and Nitrogen $(60 \mathrm{~kg} \mathrm{~N}$ $\left.\mathrm{ha}^{-1}\right)+$ poultry manure $\left(60 \mathrm{~kg} \mathrm{~N} \mathrm{ha}^{-1}\right)$ was 85 and $83 \%$, respectively.

Baral and Adhikari (2013) reported that 15\% yield increased when $10 \mathrm{t} \mathrm{ha}^{-1} \mathrm{FYM}$ applied with azotobacter.

Bindhani et al., (2007) reported that the application of $120 \mathrm{~kg} \mathrm{~N} \mathrm{ha}^{-1}$ resulted in tallest plant with maximum dry matter yield and leaf area index which is significantly higher t5han $80 \mathrm{~kg} \mathrm{~N} \mathrm{ha}^{-1}$. They also reported a significant increase in makeable baby corn plant ${ }^{-1}$ fresh weight, length and girth with the application of $120 \mathrm{~kg} \mathrm{~N} \mathrm{ha}^{-1}$.

Bindhani et al., (2008) reported that

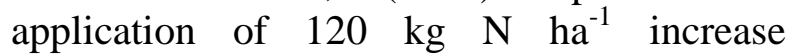
significantly higher plant height, dry matter production and leaf area index over other treatment including control.

Dilshad et al., (2010) observed that application of RDF $\left(120 \mathrm{~kg} \mathrm{~N}+90 \mathrm{~kg} \mathrm{P}_{2} \mathrm{O}_{5}+\right.$ $60 \mathrm{~kg} \mathrm{~K}_{2} \mathrm{O} \mathrm{ha}^{-1}$ ) or 50 per cent of RDF + FYM $10 \mathrm{t} \mathrm{ha}^{-1}+$ bio powder resulted in significantly greater plant height of maize over other treatments including control.

El-Kholy et al., (2005) noted that application of Azospirillum brasilense and soil yeast Rhodotorula glutinis in the presence of $100 \%$ NPK gave significant increases in plant height, leaf area index, grain and straw yield of maize over $100 \%$ NPK alone.

Kar et al., (2006) reported significantly higher number of cobs plant ${ }^{-1}$, length of cob, girth of $\mathrm{cob}$, grains $\mathrm{cob}^{-1}$ and weight of cob of sweet corn with application of $80 \mathrm{~kg} \mathrm{~N} \mathrm{ha}{ }^{-1}$ over control.

Kumar et al., (2017) observed that application of $\mathrm{S}$ and $\mathrm{Zn}$ has resulted in significant improvement for crude protein, $\mathrm{Ca}$, ash in baby corn. Application of $125 \%$ RDF (187.593.7-75 $\mathrm{kg} \mathrm{ha}^{-1}$ ) and $50 \mathrm{~kg} \mathrm{~S} \mathrm{ha}{ }^{-1}$ along with $10 \mathrm{~kg} \mathrm{Zn} \mathrm{ha}{ }^{-1}$ has great impact on corn production in maximum corn yield, fodder yield, nutrient content and monetary returns to the growers.

Kumar et al., (2017) revealed that treatment $\mathrm{T}_{3}(150 \% \mathrm{RDF})$ recorded significantly higher growth parameters and yield attributes viz. plant height $(201.90 \mathrm{~cm})$, number of grains $\mathrm{cob}^{-1}$ (393.20), test weight (223.25 g) and grain yield $\left(52.05 \mathrm{q}\right.$ ha $\left.\mathrm{ha}^{-1}\right)$ which was closely followed by treatment $\mathrm{T}_{5}(\mathrm{RDF}+5$ tons FYM ha ${ }^{-1}$ and recorded plant height $(200.30 \mathrm{~cm})$, number of grains $\mathrm{cob}^{-1}(391.95)$, test weight (223.15 g) and grain yield (51.70 $\mathrm{q}$ ha $\mathrm{ha}^{-1}$ ) and was found to be at par to treatment $\mathrm{T}_{3}$.

Mehta et al., (2011) noted the maximum dry matter accumulation, leaf area index and crop growth rate in maize with application of 275 $\mathrm{kg} \mathrm{ha}^{-1} \mathrm{~N}$ which was statistically at par with $250 \mathrm{~kg}$ nitrogen $\mathrm{ha}^{-1}$ but significantly higher over control.

Mehta et al., (2005) reported significant increase in cobs plant $^{-1}$ of maize with application of $100 \%$ RDF along with FYM at $10 \mathrm{t} \mathrm{ha}^{-1}$ over control.

Sahoo and Mahapatra (2005) reported significant increase in cobs plant ${ }^{-1}$ and weight of cob of maize were noted with application of increasing levels of nitrogen fertilizers.

Satish et al., (2011) reported higher grain (4402 kg ha ${ }^{-1)}$ and straw (5888 kg ha $\left.{ }^{-1}\right)$ yield in summer maize in treatments with both 
organic and inorganic fertilizers in kharif followed by 100 percent NPK in summer season, thus showing the beneficial effect of organic sources of nutrients on the succeeding crop and also improving the soil fertility levels.

Sepat and Kumar (2007) observed significant increases in plant height and dry matter accumulation of maize crop with application of increasing levels of nitrogen up to $120 \mathrm{~kg}$ $\mathrm{ha}^{-1}$.

Shabnam et al., (2011) state that application of FYM @ 5 t ha ${ }^{-1}$ and lime @ $0.3 \mathrm{t} \mathrm{ha}^{-1}$ recorded maximum dry matter accumulation, leaf area index and crop growth rate and produced higher grain (4.162 $\left.\mathrm{t} \mathrm{ha}^{-1}\right)$ and stover $\left(9.823 \mathrm{t} \mathrm{ha}^{-1}\right)$ yields of maize under red and lateritic soils of Ranchi.

Shrivas et al., (2007) reported that application of $33.33 \%(\mathrm{RN})$ through non- edible oil cakes, $33.33 \%$ (RN) through cow dung manure and $33.33 \%(\mathrm{RN})$ through enriched compost recorded higher plant growth of maize over rest of treatments.

Singh and Yadav (2007) found that application of $100 \%$ RDF $(90 \mathrm{~kg} \mathrm{~N}+17.5 \mathrm{~kg}$ $\mathrm{P}$ ha $^{-1}$ ) significantly improved plant height, dry matter production and leaf area index of maize over 75 per cent of RDF.

Singh et al., (2007) reported that application of $40 \mathrm{~kg} \mathrm{~N}+30 \mathrm{~kg} \mathrm{P} 2 \mathrm{O} 5+10 \mathrm{t} \mathrm{FYM} \mathrm{ha}^{-1}+$ Azotobacter +VAM significantly enhanced plant height and dry matter production of maize over other treatments.

Sujatha et al., (2008) reported that application of sunhemp green manure + poultry manure + $100 \%$ RDN gave significantly higher total dry matter accumulation plant $^{-1}$, leaf area index and cob yield plant ${ }^{-1}$ in maize over rest of treatment combinations.
Thirupathi et al., (2016) reported that applicatio0n of $\mathrm{N}$ and S @ 225 and $60 \mathrm{~kg} \mathrm{ha}^{-1}$ recorded highest grain yield, stover yield, crude protein content and $\mathrm{B}: \mathrm{C}$ ratio than other $\mathrm{N}$ and $\mathrm{S}$ contribution but it was on par with $\mathrm{N}$ and S@225 and $80 \mathrm{~kg} \mathrm{ha}^{-1}$.

Verma et al., (2006) found significant increase in plant height, dry matter production, leaf area index, crop growth rate and net assimilation rate at 30, 60 and 90 DAS of maize crop with application of NPK at 90,30 and $15 \mathrm{~kg} \mathrm{ha}^{-1,}$ respectively over control.

Yadhav and Christopher Lourduraj (2006) reported that the application of organic manures, FYM, poultry manure, green leaf manure and panchagavya spray resulted in significant increase yield attributes of sweet corn such as cob length, cob diameter and number of grains per cob.

\section{Materials and Methods}

The experiment was conducted on Maize during kharif season of 2017 under natural condition at field no. 6 Student's Instructural Farm at Chandra Shekhar Azad University of Agriculture and Technology, Kanpur. The soil of the experimental field was alluvial in origin. Soil sample $(0-15 \mathrm{~cm})$ depths were initially drawn from randomly selected parts of the field before sowing. The quantity of soil sample was reduced to about $500 \mathrm{gm}$ through quartering technique. The soil sample was then subjected to mechanical and chemical analysis in order to determine the textural class and fertility status the soils were sampled to a depth of $0-30 \mathrm{~cm}$ of the soil, airdried and sieved $(2 \mathrm{~mm})$ for soil analyses. Some physical and chemical properties of soils are given in Table 1.

Maize variety Azad Uttam was taken for study. In the present experiment 10 treatments 
$\mathrm{T}_{1}(125 \% \mathrm{RDN}), \mathrm{T}_{2}(100 \% \mathrm{RDN}), \mathrm{T}_{3}(100 \%$ $\mathrm{RDN}+25 \% \mathrm{~N} \mathrm{FYM}), \mathrm{T}_{4}(100 \% \mathrm{RDN}+25 \%$ $\left.\mathrm{N} \mathrm{FYM}+\mathrm{S}_{30}\right), \mathrm{T}_{5}(100 \% \mathrm{RDN}+25 \% \mathrm{~N}$ FYM $\left.+\mathrm{S}_{30}+\mathrm{Zn}_{5}\right), \mathrm{T}_{6}(75 \% \mathrm{RDN}), \mathrm{T}_{7}(75 \% \mathrm{RDN}+$ $25 \%$ N FYM $), \mathrm{T}_{8}(75 \% \mathrm{RDN}+25 \% \mathrm{~N}$ FYM $\left.+\mathrm{S}_{30}\right), \mathrm{T}_{9}\left(75 \% \mathrm{RDN}+\mathrm{FYM}+\mathrm{S}_{30}+\mathrm{Zn}_{5}\right), \mathrm{T}_{10}$ (Control)were laid out in Randomized Block Design(RBD) with three replications having plot size 5 x 4 meter square. Doses of fertilizers are applied @ $120 \mathrm{Kg} \mathrm{N}, 60 \mathrm{Kg}$ $\mathrm{P}_{2} \mathrm{O}_{5}, 40 \mathrm{Kg} \mathrm{K}_{2} \mathrm{O} / \mathrm{ha} 30 \mathrm{Kg} \mathrm{S} / \mathrm{ha}, 5 \mathrm{Kg} \mathrm{Zn} / \mathrm{ha}$ and Organic manure 60 tonne/ha through Urea, D.A.P and Murate of Potash, Elemental sulphur, Zinc oxide and Farm Yard Manure. Sowing is done@ 20 kg seed ha ${ }^{-1}$ maize variety Azad Uttam was used and sown on 22 June 2017. Row to row and plant to plant distance remain 60 and 20 respectively. Seed were sown about 5-6 cm depth

\section{Field preparation}

The experimental field was ploughed once with soil turning plough fallowed by two cross harrowing. After each operation, planking was done to level the field and to obtain the fine tilth. Finally layout was done and plots were demarked with small sticks and rope with the help of manual labour in each block. Application of fertilizers: The crop was fertilized as per treatment. The recommended dose of nutrient i.e. $\mathrm{N}, \mathrm{P}$, and $\mathrm{K}$ was applied @ 120: 60: $40 \mathrm{~kg} \mathrm{ha}^{-1}$ respectively. Time and method of fertilizer: Half does $\mathrm{N}_{2}$ and total phosphorus, potash, zinc and sulphur were applied as basal dressing. Remaining dose of nitrogen was applied through top dressing after knee-high stage. Well decompose FYM applied @60 t ha $^{-1} 15$ day after sowing. Seed Treatment: To ensure the seeds free from seed borne diseases, seeds were treated with thiram $75 \%$ WDP (1.5g/kg of seed). Seed and sowing: 20 $\mathrm{kg}$ seed ha ${ }^{-1}$ maize variety Azad Uttam was used and sown on 22 June 2017. Row to row and plant to plant distance remain 60 and 20 respectively. Seed were sown about $5-6 \mathrm{~cm}$ depth. Intercultural operations: Weeding and hoeing were done with khurpi and hand hoe after germination. Irrigation: Tube-well was the source of irrigation. Irrigation was provided in the crop as and when required. Harvesting: The crop was harvested at proper stage of maturity as determined by visual observations. Half meter length on either end of each plot and two border rose from each side as border were first removed from the field to avoid error. The crop in net plot was harvested for calculation on yield data. Produce was tied in bundles and weighted for biomass yield. Threshing of produce of each net crop was done by manually.

\section{Yield of crop}

\section{Grain yield}

The clean and dried grains from each plot weighed with the help of electronic balance in $\mathrm{kg} / \mathrm{ha}$ and converted into q/ha. Stalk Yield:Stalk yield can be obtained by subtracting grain yield from the biological yield.

\section{Observations recorded}

The observations were recorded as per the procedure described below. For this purpose 5 plants were selected randomly in each net plot and were tagged with a level for recording various observations on growth and yield parameters. Biometric observation: Biometric observation such as plant population, average plant height at maturity, number of cobs, length of cobs, test weight of 1000 grain, cob girth, number of grain, number of row were recorded treatment wise grain and stalk yields were recorded per plot and converted into quintal ha ${ }^{-1}$.

\section{Soil analysis}

Mechanical separates:- Soil separates analyzed by International pipette method as described by the Piper (1966). pH:- $\mathrm{pH}$ of the 
soil determined by using soil water suspension (1:2.5) with the help of digital $\mathrm{pH}$ meter. EC:- EC also determined using soil water suspension (1:2.5) with help of conductivity meter (Jackson, 1967). Organic carbon:- Organic Carbon was determined by Walkley and Black's rapid titration method as described by Jackson (1967). Available Nitrogen:- It was determined by Alkaline Potassium Permagnate Method described by Subbiah and Asija (1956). Available Phosphorus:- It is determined by Olsen's method using $0.5 \mathrm{M} \mathrm{NaHCO}_{3}$ (Olsen et al., 1954). Available Potassium:- Potassium is determined by using Neutral Normal Ammonium Acetate (pH 7.0) by Flame Photometer. Available Sulphur:- Available Sulphur was determined by turbidimetric method (Chesnin and Yien,1950) after extraction with $0.15 \% \mathrm{CaCl}_{2}$ solution. Available Zinc:- Available $\mathrm{Zn}$ is determined by Atomic Absorption Spectrophotometer with the help of DTPA extractant (Lindsey and Norvell, 1978).

\section{Statistical analysis}

The data on various characters studied during the course of investigation were statistically analyzed for randomized block design. Wherever treatment differences were significant ("F" test), critical differences were worked out at five per cent probability level. The data obtained during the study were subjected to statistical analysis using the methods advocated by Chandel (1990).

\section{Results and Discussion}

Impact of INM on growth and yield attributes of maize

\section{Growth attributes}

\section{Plant population plot $^{-1}$}

Data in regard with plant population plot $^{-1}$ was recorded at the time of crop harvest are depicted in table 4.1 and figure 1 showed nonsignificant variation in plant population within all the treatments. Maximum number of plant plot $^{-1} \mathrm{ha}^{-1}$ (246) was recorded with $100 \% \mathrm{RDN}+25 \% \mathrm{~N} \mathrm{FYM}+30 \mathrm{~kg}+5 \mathrm{~kg} \mathrm{Zn}$ $\mathrm{ha}^{-1}$ followed by (244) with $75 \% \mathrm{RDN}+25 \%$ $\mathrm{N} \mathrm{FYM} \mathrm{+} 30 \mathrm{~kg} \mathrm{~S}+5 \mathrm{~kg} \mathrm{Zn} \mathrm{ha}{ }^{-1}$ and minimum (232) at control $\left(\mathrm{T}_{10}\right)$. Integration of FYM, sulphur and zinc showed nonsignificant variation in plant population when applied with $75 \%$ RDN and $100 \%$ RDN.

\section{Plant height}

Data pertaining to plant height given in table 4.1 and figure 1 showed linear variation in all the treatments. Maximum plant height $195 \mathrm{~cm}$ was recorded with $\mathrm{T}_{5}(100 \% \mathrm{RDN}+25 \% \mathrm{~N}$ $\mathrm{FYM}+30 \mathrm{~kg} \mathrm{~S}+5 \mathrm{~kg} \mathrm{Zn} \mathrm{ha}^{-1}$ ) followed by $244 \mathrm{~cm}$ with $\mathrm{T}_{9}(75 \% \mathrm{RDN}+25 \% \mathrm{~N} \mathrm{FYM}+$ $30 \mathrm{~kg} \mathrm{~S}+5 \mathrm{~kg} \mathrm{Zn} \mathrm{ha}^{-1}$ ) and minimum $179 \mathrm{~cm}$ at control $\left(\mathrm{T}_{10}\right)$. It is also obvious from the data that plant height increased in all the treatments in comparison to control but the increase in plant height was recorded nonsignificant. Integration of sulpher, zinc and FYM with $100 \%$ RDN and $75 \%$ RDN also influenced plant height but the increase was plant height recorded non-significant.

\section{Yield attributes}

\section{Number of cob plant $^{-1}$}

It is visualized from the data given in table 4.2 and figure 2 showed that number of cob plant $^{-1}$ influenced significantly in all the treatment over to control. Maximum number of cob (1.6 plant $\left.{ }^{-1}\right)$ was recorded with $\mathrm{T}_{5}(100$ $\% \mathrm{RDN}+25 \% \mathrm{~N} \mathrm{FYM}+30 \mathrm{~kg} \mathrm{~S}+5 \mathrm{~kg} \mathrm{Zn}$ ha $\left.^{-1}\right)$ followed by $\left(1.48\right.$ cob plant $\left.^{-1}\right) \mathrm{T}_{9}(75 \%$ $\mathrm{RDN}+25 \% \mathrm{~N} \mathrm{FYM}+30 \mathrm{~kg} \mathrm{~S}+5 \mathrm{~kg} \mathrm{Zn}$ $\left.\mathrm{ha}^{-1}\right)$ and minimum (1.02 cob plant $\left.{ }^{-1}\right)$ at control $\left(\mathrm{T}_{10}\right)$. Integration of $\mathrm{S}, \mathrm{Zn}$ and FYM showed slight increase in number of cob plant $^{-1}$ when applied with $100 \%$ RDN and $75 \%$ RDN treatments. Variation in number of 
cobs plant ${ }^{-1}$ within $75 \% \mathrm{RDN}$ and $100 \%$ RDN and $125 \%$ RDN was found nonsignificant.

\section{Girth of cob}

Girth of cob as effected by different treatment are given in table 4.2 And figure 2 showed linear and non-significant variation within all the treatments. Maximum cob girth $11.7 \mathrm{~cm}$ was recorded with $\mathrm{T}_{5}(100 \% \mathrm{RDN}+25 \% \mathrm{~N}$ $\left.\mathrm{FYM}+30 \mathrm{~kg} \mathrm{~S}+5 \mathrm{~kg} \mathrm{Zn} \mathrm{ha}{ }^{-1}\right)$ followed by 11.56 with $\mathrm{T}_{9}(75 \% \mathrm{RDN}+25 \% \mathrm{~N} \mathrm{FYM} \mathrm{+}$

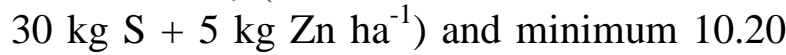
at control $\left(\mathrm{T}_{10}\right)$. It was also observed that cob girth $\mathrm{cm}^{-1}$ increased significantly in all the treatment in comparison to control. Integration of S, FYM and $\mathrm{Zn}$ showed nonsignificant increase in cob girth when applied with $100 \%$ RDN and $75 \%$ RDN treatment.

\section{Cob length cm}

Data in respect cob length was given in table 4.3 and illustrated in figure 3 showed significant variation in all the treatment. Maximum cob length $(14.40 \mathrm{~cm})$ was recorded with $\mathrm{T}_{5}(100 \% \mathrm{RDN}+25 \% \mathrm{~N} F Y M$ $\left.+30 \mathrm{~kg} \mathrm{~S}+5 \mathrm{~kg} \mathrm{Zn} \mathrm{ha}^{-1}\right)$ followed by (14.20 cm) $\mathrm{T}_{9}(75 \% \mathrm{RDN}+25 \% \mathrm{~N} \mathrm{FYM}+30 \mathrm{~kg} \mathrm{~S}$ $\left.+5 \mathrm{~kg} \mathrm{Zn} \mathrm{ha}{ }^{-1}\right)$ and minimum $(12.5 \mathrm{~cm})$ at control $\left(\mathrm{T}_{10}\right)$. It was also observed that cob length increased significantly in all the treatment in comparison to control $\left(\mathrm{T}_{10}\right)$. Integration of S, FYM and $\mathrm{Zn}$ influenced cob length significantly when applied with $100 \%$ RDN and $75 \%$ RDN treatments. Variation in cob length within 75\% RDN, 100 RDN\% and $125 \%$ RDN was also found significant.

\section{Number of rows $\operatorname{cob}^{-1}$}

Number of rows $\mathrm{cob}^{-1}$ varied from 7.66 to 11.33 and variation in number of rows $\mathrm{cob}^{-1}$ within all the treatments was found nonsignificant. It is also obvious from the data given in table 4.3 and figure 3 showed no. of rows $\mathrm{cob}^{-1}$ increase significantly in all the treatment over to control. Integration of $\mathrm{S}, \mathrm{Zn}$, and FYM showed slight increase in number of rows $\mathrm{cob}^{-1}$ but the increase was found nonsignificant. Variation in number of rows $\mathrm{cob}^{-1}$ within $75 \%$ RDN, $100 \%$ RDN and $125 \%$ RDN was also found non-significant.

\section{Number of grains row cob $^{-1}$}

Data in regard to Number of grains row $\mathrm{cob}^{-1}$ given in table 4.4 and figure 4 showed significant increase in all the treatment over control. Maximum number of grain (19.6 $\left.\mathrm{cob}^{-1}\right)$ was recorded with $\mathrm{T}_{5}(100 \% \mathrm{RDN}+$ $25 \% \mathrm{~N} \mathrm{FYM}+30 \mathrm{~kg} \mathrm{~S}+5 \mathrm{~kg} \mathrm{Zn} \mathrm{ha}{ }^{-1}$ ) followed by $\left(19.0 \mathrm{cob}^{-1}\right) \mathrm{T}_{9}(75 \% \mathrm{RDN}+25 \%$ $\mathrm{N} \mathrm{FYM}+30 \mathrm{~kg} \mathrm{~S}+5 \mathrm{~kg} \mathrm{Zn} \mathrm{ha}{ }^{-1}$ ) and minimum $\left(16.0 \mathrm{cob}^{-1}\right)$ at control $\left(\mathrm{T}_{10}\right)$. Integration of $\mathrm{S}, \mathrm{Zn}$ and FYM showed significant increased in number of grains row $\mathrm{cob}^{-1}$ when applied with $100 \% \mathrm{RDN}$ and $75 \%$ RDN treatments. Variation in number of grain row $\mathrm{cob}^{-1}$ within $75 \%$ RDN, $100 \%$ $\mathrm{RDN}$ and $125 \% \mathrm{RDN}$ was also found significant.

\section{Test weight (1000 grain)}

Test weight as expressed by weight 1000 grains in gram is given in table 4.4 and figure 4. The results revealed that test weight was non-significantly influenced by the different treatments. Maximum increase in test weight was recorded $(220.50 \mathrm{gm})$ with $\mathrm{T}_{5}(100 \%$ $\mathrm{RDN}+25 \% \mathrm{~N} \mathrm{FYM}+30 \mathrm{~kg} \mathrm{~S}+5 \mathrm{~kg} \mathrm{Zn} \mathrm{ha}$ $\left.{ }^{1}\right)$ followed by (218.40 gm) $\mathrm{T}_{9}(75 \% \mathrm{RDN}+$ $\left.25 \% \mathrm{~N} \mathrm{FYM}+30 \mathrm{~kg} \mathrm{~S}+5 \mathrm{~kg} \mathrm{Zn} \mathrm{ha}^{-1}\right)$ and minimum $(214.60 \mathrm{gm})$ at control $\left(\mathrm{T}_{10}\right)$. It was also observed that all the treatments showed significant increase in test weight over control. Integration of $\mathrm{S}, \mathrm{FYM}$ and $\mathrm{Zn}$ showed positive effects when applied with $100 \%$ RDN and $75 \%$ RDN treatments but the increase was found non- significant. Variation 
in test weight within $75 \% \mathrm{RDN}, 100 \% \mathrm{RDN}$ and $125 \%$ RDN was recorded significant.

\section{Yield}

\section{Biological yield}

It is apparent from the data given in table 4.5 and figure 5 that biological yield of maize increase significantly in all the treatments in comparison to control $\left(\mathrm{T}_{10}\right)$ maximum biological yield (133.24 q ha $\left.{ }^{-1}\right)$ was recorded with $\mathrm{T}_{5}(100 \% \mathrm{RDN}+25 \% \mathrm{~N} \mathrm{FYM}+30 \mathrm{~kg}$ $\left.\mathrm{S}+5 \mathrm{~kg} \mathrm{Zn} \mathrm{ha}^{-1}\right)$ followed by $\left(123.88 \mathrm{q} \mathrm{ha}^{-1}\right)$ with $\mathrm{T}_{9}(75 \% \mathrm{RDN}+25 \% \mathrm{~N} \mathrm{FYM}+30 \mathrm{~kg}$ $\left.\mathrm{S}+5 \mathrm{~kg} \mathrm{Zn} \mathrm{ha}^{-1}\right)$ and minimum $\left(78.75 \mathrm{q} \mathrm{ha}^{-1}\right)$ at control $\left(\mathrm{T}_{10}\right)$. Variation in biological yield within 75\% RDN, 100\% RDN and 125\% RDN was found significant. Integration of $S$, FYM and $\mathrm{Zn}$ also showed significance increase in biological yield when applied with $75 \%$ RDN and $100 \%$ RDN treatments.

\section{Grain yield}

It is apparent from the data depicted in table 4.5 and illustrated in figure 5 showed that all the treatment significantly influenced the grain yield over control. Higher grain yield $\left(35.25 \mathrm{q} \mathrm{ha}^{-1}\right)$ was recorded with $\mathrm{T}_{5}(100 \%$ $\mathrm{RDN}+25 \% \mathrm{~N} \mathrm{FYM}+30 \mathrm{~kg} \mathrm{~S}+5 \mathrm{~kg} \mathrm{Zn} \mathrm{ha}$ $\left.{ }^{1}\right)$ which was (88\%) higher to the lowest grain yield (18.75 q ha $\left.{ }^{-1}\right)$ of control $\left(\mathrm{T}_{10}\right)$ and $(31.04$ $\%)$ higher to $100 \% \operatorname{RDN}\left(\mathrm{T}_{2}\right)$. Integration of $30 \mathrm{~kg}$ sulphur ha ${ }^{-1}$ with $100 \% \mathrm{RDN}+25 \% \mathrm{~N}$ FYM produced $(11.87 \%)$ more grain yield in comparison to $100 \% \mathrm{RDN}+25 \% \mathrm{~N} \mathrm{FYM}$ $\left(\mathrm{T}_{3)}\right.$. Likewise integration of $5 \mathrm{~kg}$ zinc with $100 \%+25 \%$ N FYM + $30 \mathrm{~kg}$ sulphur $\mathrm{ha}^{-1}$ influenced $(8.46 \%)$ higher grain yield in comparison to $100 \% \mathrm{RDN}+25 \% \mathrm{~N} \mathrm{FYM} \mathrm{+}$ $30 \mathrm{~kg}$ sulphur ha ${ }^{-1}$. Super imposition of $25 \%$ $\mathrm{N}$ through FYM with 100\% RDN $\left(\mathrm{T}_{3}\right)$ produced $(7.99 \%)$ higher grain yield over $100 \%$ RDN $\left(\mathrm{T}_{2}\right)$. Variation in grain yield within $75 \%$ RDN and 100\% RDN was found significant. It was also observed that treatment receiving $125 \% \quad\left(\mathrm{~T}_{1}\right)$ inorganic fertilizer produced higher grain yield in comparison to $100 \% \mathrm{RDN}$ and $25 \% \mathrm{~N}$ FYM $\left(\mathrm{T}_{3}\right)$ but the increase was found nonsignificant. Substitution of $25 \%$ N FYM with $75 \%$ RDN produced lower grain yield than $100 \%$ RDN but yield difference within these treatment was found comparable and at par. It is interesting to show that integration of FYM, sulphur and $\mathrm{Zn}$ showed higher increase in grain yield when applied with $75 \% \mathrm{RDN}$ in comparison to $100 \%$ RDN treatment.

\section{Stalk yield}

Data in regard to stalk yield given in table 4.5 and figure 5 showed significant increase in all the treatments in comparison to control. Maximum stalk yield (97.99 $\left.\mathrm{q} \mathrm{ha}^{-1}\right)$ was recorded with $\mathrm{T}_{5}(100 \% \mathrm{RDN}+25 \% \mathrm{~N}$ FYM $+30 \mathrm{~kg} \mathrm{~S}+5 \mathrm{~kg} \mathrm{Zn} \mathrm{ha}^{-1}$ ) which was (63.31\%) higher than control. Integration of FYM, sulphur and zinc produced $85.69 \mathrm{q} \mathrm{ha}^{-1}, 91.65$ $\mathrm{q} \mathrm{ha}{ }^{-1}$ and $97.99 \mathrm{q} \mathrm{ha}^{-1}$ over yield when applied with $100 \%$ RDN and $6.02 \%, 7.30 \%$ and $7.35 \%$ more when applied with $75 \%$ RDN treatment respectively. Variation in stalk yield within $75 \%$ RDN, $100 \%$ RDN and $125 \% \mathrm{RDN}$ was found significant. It was also observed that substitution of $25 \% \mathrm{~N}$ FYM produced stalk yield at par to $100 \%$ RDN. Super imposition of $25 \% \mathrm{~N}$ through FYM with $100 \%$ RDN also produced stalk yield at par to $125 \%$ RDN.

\section{Impact of INM on growth attributes, yield} attributes and yield

The study encompasses observations on growth parameters and yield attributing characters were taken. The characters included in study were plant population plot $^{-1}$, plant height $(\mathrm{cm}$.$) at harvest stage of the crop,$ no. of cob plant ${ }^{-1}$, girth of cob $(\mathrm{cm}$.), no. of rows $\mathrm{cob}^{-1}$, no. of grain $\mathrm{cob}^{-1}$ and test weight 
(1000 grain) gm. At the harvest the data were recorded on biological yield, grain yield and stalk yield.

\section{Growth attributes}

\section{Plant population}

Plant population varied from 234 to 246 in all the treatment and variation in plant population within all the treatment was noted nonsignificant.

This indicated that nutrient treatment was affected in plant population. Plant population could be affected due to seeding, germination percentage etc. These findings are related to the findings of Verma et al., (2006), Jena et al., (2013) and Shrivas et al., (2007)

\section{Plant height}

Plant height was measured at harvest stage. Perusal of the data given in table 4.1 and figure 1 showed that plant height increase significantly in all the treatment over control. Plant height varied from 174 to $195 \mathrm{~cm}_{\text {plant }}{ }^{-1}$ within all the treatments. Addition of FYM, S, $\mathrm{Zn}$ influenced plant height when applied with $100 \%$ RDN and $75 \%$ RDN. Significant variation in plant height was noted within $75 \%$ RDN, $100 \%$ RDN and $125 \%$ RDN.

Maximum plant height $195 \mathrm{~cm}$. was recorded with $\mathrm{T}_{5}(100 \% \mathrm{RDN}+25 \% \mathrm{~N} \mathrm{FYM}+30 \mathrm{~kg}$ $\mathrm{S}+5 \mathrm{~kg} \mathrm{Zn} \mathrm{ha}^{-1}$ ) which were $35.71 \%$ higher than control. This indicates that the nutrient application resulted in augmented photosynthetic activity due to combined and balance effect of nutrients in maize.

Significant increase in cell division and growth was also manifested in terms of plant height. Increase in plant height due to integration of $\mathrm{S}$ and $\mathrm{Zn}$ and organic manure with $100 \%$ inorganic fertilizers. Similar results have been reported by Bindhani et al., (2007), El-Kholy et al., (2005), Mehta et al., (2011), Kumar (2008) and Singh and Yadav (2007).

\section{Yield attributes}

Yield attributes parameter that has been given in table 4.2 to table 4.4 and figure 2 to 4 showed that significant increase in yield attributing parameter in all the treatments over control. Maximum yield attributing parameter was recorded with $\mathrm{T}_{5}(100 \% \mathrm{RDN}$ $\left.+25 \% \mathrm{~N} \mathrm{FYM} \mathrm{+} 30 \mathrm{~kg} \mathrm{~S}+5 \mathrm{~kg} \mathrm{Zn} \mathrm{ha}{ }^{-1}\right)$ followed by $\mathrm{T}_{9}(75 \% \mathrm{RDN}+25 \% \mathrm{~N} \mathrm{FYM}+$

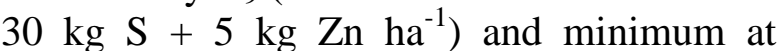
control $\left(\mathrm{T}_{10}\right)$. Addition of $\mathrm{S}, \mathrm{Zn}$ and FYM with $100 \%$ RDN and $75 \%$ RDN also accelerate yield attributing parameters but the increase in yield attributing parameters in general was found non-significant. Increase in yield attributing parameters within $75 \%$ RDN, $100 \% \mathrm{RDN}$ and $125 \% \mathrm{RDN}$ were noted in general significant. Increase in yield attributing parameters might be attributed to increase cell expansion and various metabolic processes in the presence of adequate available nutrient. Results in this study are agreement with those of following workers Sahoo and Mahapatra (2005), Kar et al., (2006), Mehta et al., (2011) and Kumar (2008).

\section{Impact of INM on grain and stalk yield}

A perusal of the data presented in table 4.5 and illustrated in figure clearly revealed that all the treatment significantly influenced the grain and stalk yield over control. The highest grain yield $35.25 \mathrm{q} \mathrm{ha}^{-1}$ and stalk yield 97.99 $\mathrm{q}$ ha ${ }^{-1}$ were recorded with $\mathrm{T}_{5}(100 \% \mathrm{RDN}+25$ $\% \mathrm{~N} \mathrm{FYM}+30 \mathrm{~kg} \mathrm{~S}+5 \mathrm{~kg} \mathrm{Zn} \mathrm{ha}^{-1}$ ) which was $88 \%$ and $63.31 \%$ higher than yield of control $\left(\mathrm{T}_{10}\right)$. Integration of $30 \mathrm{~kg} \mathrm{~S} \mathrm{ha}{ }^{-1}$ produced $11.87 \%$ and $13.01 \%$ higher grain and $6.95 \%$ and $5.67 \%$ stalk yield with $100 \%$ 
and $75 \%$ RDN. Like-wise S integration of 5 $\mathrm{kg} \mathrm{Zn}$ also produces $8.46 \%$ and $8.84 \%$ higher grain and $6.91 \%$ and $6.87 \%$ stalk yield with $100 \%$ and $75 \%$ RDN. Super imposition of FYM with $100 \%$ RDN and substitution of $25 \% \mathrm{~N}$ through FYM with $75 \% \mathrm{RDN}$ also influenced $7.99 \% 8.82 \%$ higher grain and $5.49 \%$ and $7.07 \%$ higher stalk yield. It is also obvious from the data that $100 \%$ RDN produced $10.47 \%$ more grain and $7.61 \%$ higher stalk yield over $75 \%$ RDN. Application 125\% RDN also produced 8.55\% higher grain and $5.31 \%$ higher stalk over $100 \% \mathrm{RDN}$. It is interesting to report here that integration of $25 \% \mathrm{~N}$ through FYM with $100 \%$ RDN produced grain and stalk yield on par to $125 \%$ RDN.

Table.1 Some properties of the $<2 \mathrm{~mm}$ fraction of the top $30 \mathrm{~cm}$ of soil used for the site

\begin{tabular}{|c|l|l|}
\hline S.No. & Particulars & Values \\
\hline A. & Mechanical separates & \\
\hline $\mathbf{1 .}$ & Sand $(\%)$ & 59.6 \\
\hline $\mathbf{2 .}$ & Silt $(\%)$ & 17.4 \\
\hline $\mathbf{3 .}$ & Clay $(\%)$ & 23.00 \\
\hline $\mathbf{4 .}$ & Textural Class & Sandy loam \\
\hline B. & Physico-chemical properties & \\
\hline $\mathbf{5 .}$ & pH $(1: 2.5)$ & 8.2 \\
\hline $\mathbf{6 .}$ & EC $(1: 2.5)\left(\mathrm{dS} / \mathrm{m}^{\text {at }} 25^{\circ} \mathrm{C}\right)$ & 0.20 \\
\hline $\mathbf{7 .}$ & Organic Carbon $(\%)$ & 0.36 \\
\hline $\mathbf{8 .}$ & Available Nitrogen $(\mathrm{kg} / \mathrm{ha})$ & 190.00 \\
\hline $\mathbf{9 .}$ & Available Phosphorus $(\mathrm{kg} / \mathrm{ha})$ & 13.50 \\
\hline $\mathbf{1 0 .}$ & Available Potassium $(\mathrm{kg} / \mathrm{ha})$ & 182 \\
\hline $\mathbf{1 1}$. & Available Sulphur $(\mathrm{kg} / \mathrm{ha})$ & 15.80 \\
\hline $\mathbf{1 2 .}$ & Available Zinc $(\mathrm{ppm})$ & 0.56 \\
\hline $\mathbf{1 3}$ & Particle Density $\left(\mathrm{Mg} / \mathrm{m}^{3}\right)$ & 2.54 \\
\hline $\mathbf{1 4}$. & Bulk Density $\left(\mathrm{Mg} / \mathrm{m}^{3}\right)$ & 1.30 \\
\hline $\mathbf{1 5 .}$ & Pore Space $(\%)$ & 46.0 \\
\hline
\end{tabular}

Table.2 Impact of integrated nutrient management on growth attributes of maize

\begin{tabular}{|c|c|c|c|}
\hline S.No. & Treatment & Plant Population plot $^{-1}$ & Plant Height (cm) \\
\hline 1. & $\mathrm{~T}_{1}=125 \% \mathrm{RDN}$ & 240 & 191 \\
\hline 2. & $\mathrm{~T}_{2}=100 \% \mathrm{RDN}$ & 238 & 189 \\
\hline 3. & $\mathrm{~T}_{3}=100 \% \mathrm{RDN}+25 \% \mathrm{~N} \mathrm{FYM}$ & 239 & 190 \\
\hline 4. & $\mathrm{~T}_{4}=100 \% \mathrm{RDN}+25 \% \mathrm{~N} \mathrm{FYM}+\mathrm{S}_{30}$ & 243 & 193 \\
\hline 5. & $\mathrm{~T}_{5}=100 \% \mathrm{RDN}+25 \% \mathrm{~N} \mathrm{FYM}+\mathrm{S}_{30}+\mathrm{Zn}_{5}$ & 246 & 195 \\
\hline 6. & $\mathrm{~T}_{6}=75 \% \mathrm{RDN}$ & 235 & 186 \\
\hline 7. & $\mathrm{~T}_{7}=75 \% \mathrm{RDN}+25 \% \mathrm{~N} \mathrm{FYM}$ & 237 & 188 \\
\hline 8. & $\mathrm{~T}_{8}=75 \% \mathrm{RDN}+25 \% \mathrm{~N} \mathrm{FYM}+\mathrm{S}_{30}$ & 241 & 192 \\
\hline 9. & $\mathrm{~T}_{9}=75 \% \mathrm{RDN}+\mathrm{FYM}+\mathrm{S}_{30}+\mathrm{Zn}_{5}$ & 244 & 194 \\
\hline 10. & $\mathrm{~T}_{10}=$ Control & 232 & 170 \\
\hline \multicolumn{2}{|c|}{ S. E. \pm} & 5.59 & 0.325 \\
\hline \multicolumn{2}{|c|}{ C. D. (at $5 \%)$} & 16.93 & 0.973 \\
\hline
\end{tabular}


Table.3 Impact of integrated nutrient management on yield attributes of maize

\begin{tabular}{|c|c|c|c|}
\hline S.NO. & Treatments & No of cob plant ${ }^{-1}$ & Girth of $\operatorname{cob}(\mathbf{c m})$. \\
\hline 1. & $\mathrm{~T}_{1}$ & 1.35 & 11.10 \\
\hline 2. & $\mathbf{T}_{2}$ & 1.15 & 10.76 \\
\hline 3. & $\mathbf{T}_{3}$ & 1.25 & 10.85 \\
\hline 4. & $\mathbf{T}_{4}$ & 1.45 & 11.50 \\
\hline 5. & $T_{5}$ & 1.60 & 11.70 \\
\hline 6. & $T_{6}$ & 1.08 & 10.40 \\
\hline 7. & $\mathbf{T}_{7}$ & 1.12 & 10.58 \\
\hline 8. & $\mathbf{T}_{8}$ & 1.38 & 11.30 \\
\hline 9. & $T_{9}$ & 1.48 & 11.56 \\
\hline 10. & $T_{10}$ & 1.02 & 10.20 \\
\hline \multicolumn{2}{|c|}{ S.E. \pm} & 0.019 & 0.027 \\
\hline \multicolumn{2}{|c|}{ C.D. (at $5 \%$ ) } & 0.058 & 0.082 \\
\hline
\end{tabular}

Table.4 Impact of integrated nutrient management on yield attributes of maize

\begin{tabular}{|c|c|c|c|}
\hline S.No. & Treatments & Cob length $(\mathrm{cm})$ & No of rows $\operatorname{cob}^{-1}$ \\
\hline 1. & $\mathrm{~T}_{1}$ & 13.75 & 10 \\
\hline 2. & $\mathrm{~T}_{2}$ & 13.20 & 9.67 \\
\hline 3. & $\mathrm{~T}_{3}$ & 13.50 & 9.67 \\
\hline 4. & $\mathrm{~T}_{4}$ & 14.05 & 10.67 \\
\hline 5. & $\mathrm{~T}_{5}$ & 14.40 & 11.33 \\
\hline 6. & $\mathrm{~T}_{6}$ & 12.80 & 8 \\
\hline 7. & $\mathrm{~T}_{7}$ & 13.05 & 9.67 \\
\hline 8. & $\mathrm{~T}_{8}$ & 13.85 & 10.00 \\
\hline 9. & $\mathrm{~T}_{9}$ & 14.20 & 10.67 \\
\hline 10. & $T_{10}$ & 12.5 & 7.66 \\
\hline \multicolumn{2}{|c|}{ S. E. \pm} & 0.033 & 0.325 \\
\hline \multicolumn{2}{|c|}{ C. D. (at $5 \%$ ) } & 0.100 & 0.974 \\
\hline
\end{tabular}

Table.5 Effect of integrated nutrient management on yield attributes of maize

\begin{tabular}{|c|c|c|c|}
\hline S.No. & Treatments & No of grains row $\operatorname{cob}^{-1}$ & Test weight (1000 grain) (gm) \\
\hline 1. & $\mathrm{~T}_{1}$ & 17.8 & 217.20 \\
\hline 2. & $\mathrm{~T}_{2}$ & 17.20 & 216.80 \\
\hline 3. & $\mathrm{~T}_{3}$ & 17.60 & 217.05 \\
\hline 4. & $\mathrm{~T}_{4}$ & 18.08 & 218.10 \\
\hline 5. & $\mathrm{~T}_{5}$ & 19.60 & 220.50 \\
\hline 6. & $\mathrm{~T}_{6}$ & 16.80 & 215.50 \\
\hline 7. & $\mathrm{~T}_{7}$ & 17.00 & 216.30 \\
\hline 8. & $\mathrm{~T}_{8}$ & 18.20 & 217.50 \\
\hline 9. & $\mathrm{~T}_{9}$ & 19.00 & 218.40 \\
\hline 10. & $\mathrm{~T}_{10}$ & 16.00 & 214.60 \\
\hline \multicolumn{2}{|c|}{ S.E. \pm} & 0.217 & 0.811 \\
\hline \multicolumn{2}{|c|}{ C. D. (at $5 \%$ ) } & 0.649 & 2.429 \\
\hline
\end{tabular}


Table.6 Impact of integrated nutrient management on yield of maize

\begin{tabular}{|c|c|c|c|c|}
\hline S.No. & Treatments & Grain yield $\left(\mathrm{q} \mathrm{ha}^{-1}\right)$ & Stalk yield $\left(\mathrm{q} \mathrm{ha}^{-1)}\right.$ & Biological yield $\left(\mathrm{q} \mathrm{ha}^{-1}\right)$ \\
\hline 1. & $T_{1}$ & 29.20 & 85.55 & 114.75 \\
\hline 2. & $\mathbf{T}_{2}$ & 26.90 & 81.23 & 108.13 \\
\hline 3. & $\mathbf{T}_{3}$ & 29.05 & 85.69 & 114.74 \\
\hline 4. & $\mathbf{T}_{4}$ & 32.50 & 91.65 & 124.15 \\
\hline 5. & $T_{5}$ & 35.25 & 97.99 & 133.24 \\
\hline 6. & $T_{6}$ & 24.35 & 75.48 & 99.83 \\
\hline 7. & $\mathbf{T}_{7}$ & 26.50 & 80.82 & 107.32 \\
\hline 8. & $\mathbf{T}_{8}$ & 29.95 & 85.41 & 115.36 \\
\hline 9. & $T_{9}$ & 32.60 & 91.28 & 123.88 \\
\hline 10. & $\mathbf{T}_{10}$ & 18.75 & 60.00 & 78.75 \\
\hline \multicolumn{2}{|r|}{ S. E. \pm} & 0.876 & 0.559 & 1.435 \\
\hline \multicolumn{2}{|c|}{ C. D. (at $5 \%$ ) } & 2.622 & 1.674 & 4.296 \\
\hline
\end{tabular}

It was also observed that substitution of $25 \%$ $\mathrm{N}$ through FYM with $75 \%$ RDN produces grain yield at par to $100 \%$ RDN. Increase in grain and stalk yield might be due to increasing in growth and yield attributes of maize and due to integration of $\mathrm{S}, \mathrm{Zn}$ and organic manure with inorganic fertilizer. Organics besides release their own nutrient might have increase in the nutrient use efficiency of applied inorganic fertilizer in maize crop. The result of the present study is in agreement with those of several investigators Sujatha et al., (2008), Karasu (2012) and Kumar et al., (2017).

\section{Biological yield}

Impact of INM on biological yield of maize presented in table 4.5 and fig. 4.5 showed significant increase in biological yield in all the treatments over control. Maximum biological yield was $133.24 \mathrm{q} \mathrm{ha}^{-1}$ was noted with $\mathrm{T}_{5}(100 \% \mathrm{RDN}+25 \% \mathrm{~N} \mathrm{FYM}+30 \mathrm{~kg}$ $\left.\mathrm{S}+5 \mathrm{~kg} \mathrm{Zn} \mathrm{ha}{ }^{-1}\right)$ which was found $69.19 \%$ higher over the yield $78.75 \mathrm{q} \mathrm{ha}^{-1}$ of control. Addition of S, Zn and FYM also influenced biological yield when applied with 100\% RDN and 75\% RDN. Variation in biological yield within $75 \%$ RDN, 100\% RDN and
$125 \%$ RDN was noted significant. Increase in biological yield with graded dosed of RDN and integration of S, $\mathrm{Zn}$ and FYM may be due to that all the nutrient element is associated with the metabolism of nutrient in plant life cycle. These results are in the line of the findings of Abbasi et al., (2010) and Choudhary et al., (2007).

\section{References}

Abbasi, M.K., Khaliq, A., Shafiq, M., Kazmi, M. and Ali, I. (2010). Comparative Effectiveness of Urea N, Poultry Manure and their Combination in Changing Soil Properties and Maize Productivity under Rainfed Conditions in Northeast Pakistan. Experimental Agriculture, 46(2): 211-230.

Begum, M., Narayanaswamy, G., Rai, K. K. and Biswas D. R. (2007). Influence of integrated nutrient management on nitrogen and phosphorus in soil under wheat- mungbean- maize cropping system. Journal of the Indian Society of Soil Science. 55 (2): 175-183.

Bindhani, A., Barik, K.C., Garnayak, L.M. and Mahapatra, P.K. (2008). Productivity and nitrogen use efficiency 
of baby corn (Zea mays L.) at different levels and timing of nitrogen application under rainfed conditions. Indian Journal of Agricultural Sciences 78:629-631.

Bindhani, A., Barik, K.C., Garnayak, L.M. and Mahapatra, P.K. (2007). Nitrogen management in baby corn (Zea mays L.). Indian Journal of Agronomy 52: 135-138.

Choudhary, M.L., Singh, A. and Parihar, C.M. (2007). Forage production potential of maize (Zea mays L.) under different nitrogen levels and crop geometry. Agronomy Digest 7: 17-18.

Dilshad, M.D., Lone, M.I., Jilani, G., Azim Malik, M., Yousaf, M. Khalid, R. and Shamin, F. (2010). Integrated nutrient management (IPNM) on maize under rainfed condition. Pakistan Journal of Nutrition 9: 896-901.

El-Kholy, M.A., El-Ashry, S. and Gomaa, A.M. (2005). Biofertilization of maize crop and its impact on yield and grains nutrient content under low rates of mineral fertilizers. Journal of Applied Sciences Research 1: 117-121.

Kar, P.P., Barik, K.C., Mahapatra, P.K., Garnayak, L.M., Rath, B.S., Bastia, D.K. and Khanda, C.M. (2006). Effect of planting geometry and nitrogen on yield, economics and nitrogen uptake of sweet corn (Zea mays L.). Indian Journal of Agronomy 51: 43-45.

Karforma, J., Ghosh, M., Ghosh, D. C. and Mandal, S. (2012). Effect of integrated nutrient management on growth, productivity, quality and economics $\mathrm{o}++\mathrm{f}$ fodder maize in rainfed upland of Terai region of West Bengal. International Journal of Agric. Env. Biotech, 5(4): 419-427.

Kumar A., Tripathi, H.P. and Yadav, D. S. (2007) Correcting nutrient for sustainable crop production. Indian Journal of Fertilizers 2 (11): 37-44
Kumar B, Gupta RK and Bhandari AL. 2008. Soil fertility changes after longterm application of organic manure and crop residues under rice-wheat system. Journal of Indian Society of Soil Science, 56(1):80-85.

Kumar Prasanna, Halepyati, A.S., Pujari, B.T. and Desai, B.K. (2007). Effect of integrated nutrient management on productivity, nutrient uptake and economics of maize (Zea mays L.) under rainfed condition. Karnataka Journal of Agricultural Sciences 20: 03.

Kumar Rakesh, Kumawat Narendra, Kumar Sudhir, Singh Amitesh Kumar and Bohra J.S. (2017). Effects of NPKS and Zn Fertilization on, Growth, Yield and Quality of Baby corn- A Review. International Journal of Current Microbiology and applied Sciences 6 (3): 1422-1428

Kumar V and Singh AP. (2010). Long-term effect of green manuring and farmyard manure on yield and soil fertility status in rice-wheat cropping system. Journal of the Indian Society of Soil Science 58: 409-412

Kumar, A. (2008). Productivity, economics and nitrogen use efficiency of speciality corn (Zea mays) as influenced by planting density and nitrogen fertilization. Indian Journal of Agronomy 53: 306-309.

Kumar, A. and Dhar, S. (2010). Evaluation of organic and inorganic sources of nutrients in maize (Zea mays L.) and their residual effect on wheat (Triticum aestivum) under different fertility levels. Indian Journal of Agricultural Sciences 80:364-371.

Kumar, A., Singh R., Rao L.K., Singh U.K. (2008). Effect of integrated nitrogen management on growth and yield of maize (Zea mays L.) cv. PA-711Madras Agric. J. 2008; 95 (7-12): 467-472.

Mehta, S., Bedi, S. and Vashist, K.K. (2011). 
Performance of winter maize (Zea mays L.) hybrid to planting methods and nitrogen levels. Indian Journal of Agricultural Sciences 81:50-54.

Mehta, Y.K., Shaktawat, M.S., and Singhi, S.M. (2005). Influence of sulphur, phosphorus and farmyard manure on yield on yield at tributes and yield of maize (Zea mays) in southern Rajasthan condition. Indian Journal of Agronomy 50:203205.

Sahoo, S.C. and Mahapatra, P.K. (2005). Response of sweet corn (Zea mays L.) to fertility levels under on farm situation. Indian Journal of Agricultural Sciences 75:603-604.

Satish, A., Hugar, A.Y., Kusagur, N. and Chandrappa H. (2011). Effect of Integrated Nutrient Management on Soil Fertility Status and Productivity of Rice - Maize Sequence under Permanent Plot Experiment. Indian Journal of Agricultural Research, 45(4): 320-325.

Shabnam, S., Singh, M.K., Thakur, R., Upasani, R.R. and Pal S. K. (2011). Influence of Soil Ameliorant on Growth and Yield of Maize (Zea Mays L.). SAARC Journal of Agriculture. 9(1): 29-35.

Shrivas, S.K., Dash, A. C. and Urkurkar, J. S. (2007). Effect of organic sources of nutrient on growth and yield of wheat (Triticum aestivum L.). Journal of Soils and Crops 17: 38 - 41.

Singh, D. and Yadav, L.R. (2007). Effect of organic manures, chemical fertilizers and phosphorus sources on quality protein maize (Zea mays L.) Agronomy Digest 7:15-17.

Sujatha, M.G., Lingaraju, B.S., Palled, Y.B. and Ashalatha, K.V. (2008). Importance of integrated nutrient management practices in maize under rainfed condition. Karnataka Journal of Agricultural sciences 21: 334-338.

Thirupathi I., Sagar G.E. Ch. Vidya, Devi K. B. Suneetha and Sharma S. Harish Kumar (2016) Effect of nitrogen and sulphur levels on growth, yield, quality and economics of single cross hybrid maize (Zea mays L.) International Journal of Science, Environment and Technology 5 (5): 2989-

Verma, A., Nepalia, V. and Kanthaliya, P.C. (2006). Effect of nutrient supply on growth, yield and nutrient uptake by maize (Zea mays L.) - wheat (Triticum aestivum L.) cropping system. Indian Journal of Agronomy 51:3-6.

Yadhav, B.K. and Christopher Lourduraj, A. (2006). Effect of organic manures and panchagavya spray on yield attributes, yield and economics of maize (Zea mays L.) Journal Crop Research 30 (1): $1-5$.

\section{How to cite this article:}

Priyavart Mishra, U.S. Tiwari, Hanuman Prasad Pandey, R.K. Pathak and A.K. Sachan. 2019. Impact of INM on Growth and Yield of Maize (Zea mays) Crop in Central Plain Zone of Uttar Pradesh, India. Int.J.Curr.Microbiol.App.Sci. 8(04): 138-150.

doi: https://doi.org/10.20546/ijcmas.2019.804.015 